\title{
Sexual size dimorphism in Myotis nigricans (Schinz, 1821) (Chiroptera: Vespertilionidae) from south Brazil
}

\author{
Bornholdt, $R .^{\mathrm{a} *}$, Oliveira, LR. ${ }^{\mathrm{b}, \mathrm{c}}$ and Fabián, $M E .^{\mathrm{a}}$ \\ a'Departamento de Biologia Animal, Instituto de Biociências, Universidade Federal do Rio Grande do Sul - UFRGS, \\ Av. Bento Gonçalves, 9500, bloco IV, prédio 43435, sala 123, CEP 91540-000, Porto Alegre, RS, Brazil \\ ${ }^{\text {b} G r u p o ~ d e ~ E s t u d o s ~ d e ~ M a m i ́ f e r o s ~ A q u a ́ t i c o s ~ d o ~ R i o ~ G r a n d e ~ d o ~ S u l ~-~ G E M A R S, ~}$ \\ Rua Felipe Néri, 382/202, CEP 90440-150, Porto Alegre, RS, Brazil \\ 'Laboratório de Biologia Evolutiva e Conservação de Vertebrados - LABEC, Instituto de Biociências, \\ Universidade de São Paulo - USP, \\ Rua do Matão 277, Cidade Universitária, CEP 05508-090, São Paulo, SP, Brazil \\ *e-mail: reborn@terra.com.br
}

Received June 28, 2007 - Accepted September 5, 2007 - Distributed November 30, 2008

(With 3 figures)

\begin{abstract}
Among Vespertilionidae species, sexual size dimorphism is very well documented, in which females are larger than males. The differences are mainly in body weight, skull measurements and forearm length. Studies have discussed some hypothesis for this phenomenon. However, very little information is known about sexual size dimorphism in Myotis nigricans (Schinz, 1821) in Brazil. In this sense, the goal of this paper is to present a study of this phenomenon in the species. For this, we present a quantitative analysis of sexual size dimorphism assessed by traditional morphometrics. Ten skull measurements in addition to the forearm length of adult specimens were taken. Results of traditional morphometrics revealed sexual size dimorphism in five skull measurements and in the forearm length. Females were larger than males. These differences can be attributed to natural selection on large female size for increase fecundity. Bat females of the Vespertilionidae family are usually larger than males in order to perform parental care appropriately and to provide a successful reproductive process.
\end{abstract}

Keywords: Chiroptera, Vespertilionidae, Myotis nigricans, sexual size dimorphism, morphometrics.

\section{Dimorfismo sexual no tamanho do crânio de Myotis nigricans (Schinz, 1821) (Chiroptera: Vespertilionidae) no sul do Brasil}

\begin{abstract}
Resumo
Entre as espécies de Vespertilionidae, o dimorfismo sexual, no qual as fêmeas são maiores que os machos, é bem documentado. As diferenças aparecem principalmente no peso do corpo, nas medidas cranianas e no comprimento do antebraço. Estudos têm discutido algumas hipóteses para este fenômeno. Contudo, poucas são as informações conhecidas sobre dimorfismo sexual de tamanho para a espécie Myotis nigricans (Schinz, 1821) no Brasil. O objetivo deste artigo é apresentar um estudo deste fenômeno na espécie. Para isso, apresentamos uma análise quantitativa do dimorfismo sexual através da morfometria tradicional, no qual 10 medidas cranianas e o comprimento do antebraço foram tomados. Resultados da morfometria tradicional revelaram dimorfismo sexual em cinco das dez medidas cranianas e no comprimento do antebraço. Em todas as medidas, as fêmeas foram maiores que os machos. As diferenças podem ser atribuídas à seleção natural, favorecendo tamanho maior para as fêmeas para aumentar a fecundidade. Fêmeas da família Vespertilionidae são geralmente maiores a fim de desempenhar adequadamente o cuidado parental e prover processo reprodutivo com sucesso.
\end{abstract}

Palavras-chave: Chiroptera, Vespertilionidae, Myotis nigricans, dimorfismo sexual no tamanho, morfometria tradicional. 


\section{Introduction}

Among Chiroptera, mouse-eared bats (Myotis, Vespertilionidae) represent the largest genus, with more than 100 species worldwide (Simmons, 2005). Despite diversification, species of Myotis have a rather undifferentiated phenotype (Hoofer and Bussche, 2003) and correct identification may be difficult (LaVal, 1973; Bogan, 1978; Reduker, 1983; Ruedi et al., 1990; Baud and Menu, 1993; Barquez et al., 1999; Gannon et al., 2001; Ruedi and Mayer, 2001; López-Gonzales et al., 2001; Stadelmann et al., 2004). Myotis is distributed in all continents (except the Antarctic), from the boreal to sub-Antarctic zones, tropical rain forests, or semi-desert habitats. Ruedi and Mayer (2001) concluded that the numerous species of Myotis suffered independent evolution in the different biogeographic regions with subsequent convergent adaptive radiation. The same ecomorph appears to have evolved several times independently (Ruedi and Mayer, 2001). As a result, the genus represents one of the most diverse and successful radiations even among mammals.

In Brazil, six species of the genus are registered: M. albescens (E. Geoffroy, 1806), M. levis (I. Geoffroy, 1824), M. nigricans (Schinz, 1821), M. riparius Handley, 1960, M. ruber (E. Geoffroy, 1806) and M. simus Thomas, 1901 (Bianconi and Pedro, 2007). Myotis nigricans is found from South Mexico (Nayarit and Tamaulipas) to Peru, Bolivia, North Argentina, Paraguay and South Brazil (Simmons, 2005). It also occurs in Trinidad and Tobago and the Lesser Antilles (St. Martin, Montserrat and Grenada) (Simmons, 2005). This species has sociable habits and it is most common in areas modified by people, like the ceilings of buildings and houses, but it also occurs in the forest and can be found in spaces like tree barks and foliages (Barquez et al., 1999; González, 2000). Studies concluded that the species is well adapted to open-space foraging and it is also perfectly capable of aerial foraging (Siemers et al., 2001).

Among Vespertilionidae species, sexual size dimorphism is very well documented, in which females are larger than males (Ralls, 1976; Myers, 1978; Schulz, 1999), but a better understanding of the reasons for this remains a challenge. The differences are observed mainly in body weight, skull measurements and forearm length. Studies have discussed some hypothesis for this phenomenon, like the one that describes natural selection (costs of reproduction) as a determinant of sexual size dimorphism for increased fecundity (Ralls, 1976; Myers, 1978; Campbell and Kitchener, 1980). Nevertheless, sexual size dimorphism in M. nigricans in South America was not detected using body and skull measurements.

Although LaVal (1973) was a pioneer in the study of morphology in $M$. nigricans, he did not mention any data about sexual dimorphism, and even the information he had about morphological variation was not statistically tested. Myers and Wetzel (1983), throughout the analyses of body and skull linear measurements of specimens from Argentina, Bolivia and Paraguay, found no significant differences between male and female measurements. Some years later, López-Gonzales et al. (2001) studied morphological variation in M. nigricans in Paraguay and agreed with the absence of sexual dimorphism for the species in that country. The data from these authors discord with most of the data found for Vespertilionidae sexual dimorphism. Besides, there is a lack of information about M. nigricans in Brazil. For these reasons, the goal of the paper is to present a study of sexual size dimorphism in the skull of the mouseeared bat, Myotis nigricans (Schinz, 1821) (Chiroptera: Vespertilionidae) in South Brazil assessed by the traditional morphometrics method.

\section{Material and Methods}

\subsection{Sample}

Skulls and forearms of 117 adult specimens of M. nigricans (see Table 1) deposited in four Brazilian museums and institutions were examined (see Appendix). All the specimens represented the sample from South Brazil (Figure 1).

The age group was determined based on the presence of bone or cartilage epiphysis on the metacarpal-phalangeal joint from the left forth digit (Burnett and Kunz, 1982; Kunz and Anthony, 1982; Anthony, 1988).

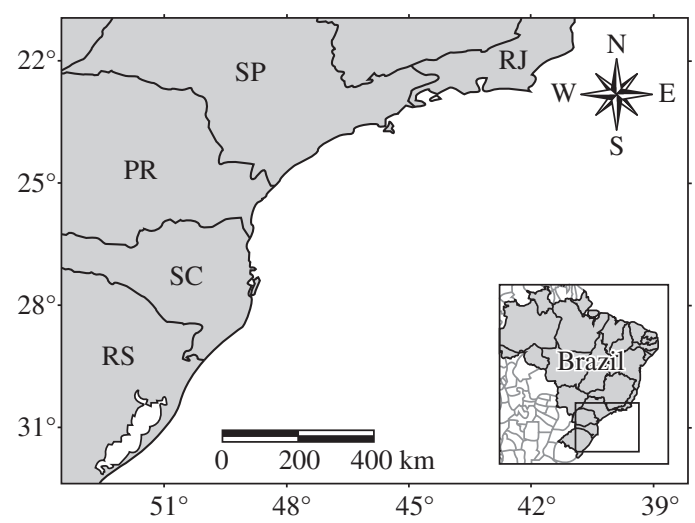

Figure 1. Map presenting the studied area in South Brazil: Paraná (PR), Santa Catarina (SC) and Rio Grande do Sul (RS) states.

Table 1. Total number (n) of Myotis nigricans adult specimens from South Brazil included in the traditional morphometrics analysis (forearm length and skull measurements) according to the genders.

\begin{tabular}{lrcc}
\hline Gender & n & $\begin{array}{c}\text { Forearm } \\
\text { length }\end{array}$ & $\begin{array}{c}\text { Skull } \\
\text { measurements }\end{array}$ \\
\hline Females & 67 & 57 & 67 \\
Males & 50 & 50 & 46 \\
Total & 117 & 107 & 113 \\
\hline
\end{tabular}




\subsection{Study area}

The region of South Brazil comprises the states of Paraná (PR), Santa Catarina (SC) and Rio Grande do $\mathrm{Sul}$ (RS) (Figure 1). The examined specimens from this area were collected between $23^{\circ}$ and $31^{\circ} \mathrm{S}$, mainly in localities covered by the Brazilian Atlantic Forest (see the Appendix for a detailed list of the sampling localities). This biome is composed of two major vegetation types: the Atlantic Rain Forest (coastal forest) and the Atlantic Semi-deciduous forest (tropical seasonal forest).

\subsection{Data analysis}

Traditional (linear) morphometrics (Marcus, 1990) were employed to visualize size differences in the skulls and forearms of males and females.

Ten linear measurements $(n=113)$ in addition to the forearm length $(n=107)$ of adult specimens were taken (Figure 2) using a Mitutoyo digital caliper (accurately $0.05 \mathrm{~mm}$ ) (see Table 1). Measurements were based on those taken by Vizotto and Taddei (1973) and Barquez et al. (1999) for bats.

The normal distribution of the data was tested using the Kolmogorov-Smirnov non-parametric test. The univariate analysis (Student's $t$-test) was employed to verify the existence of any significant differences between male and female skull and forearm. Additionally, a Principal Component Analysis (PCA) was carried out over the variance-covariance matrix of the logarithms of all skull measurements. The PCA analysis was employed to explore multivariate differences between sexes (Neff and Marcus, 1980) in order to find any a priori group. Finally, we calculated the PCA residuals of each measure by regressing it against the logarithm from the forearm length to test whether the sexes differ in relative dimensions.

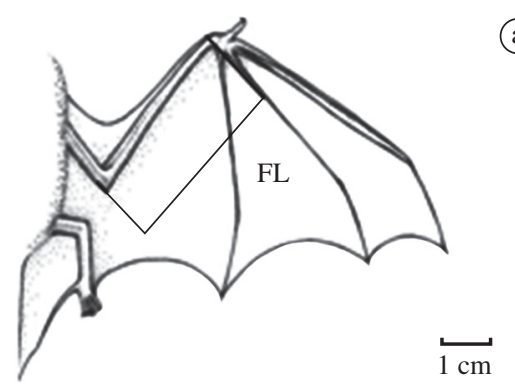

(a)

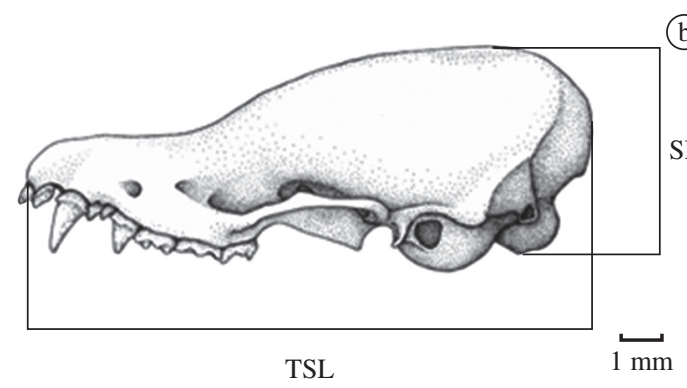

(b)

(c)
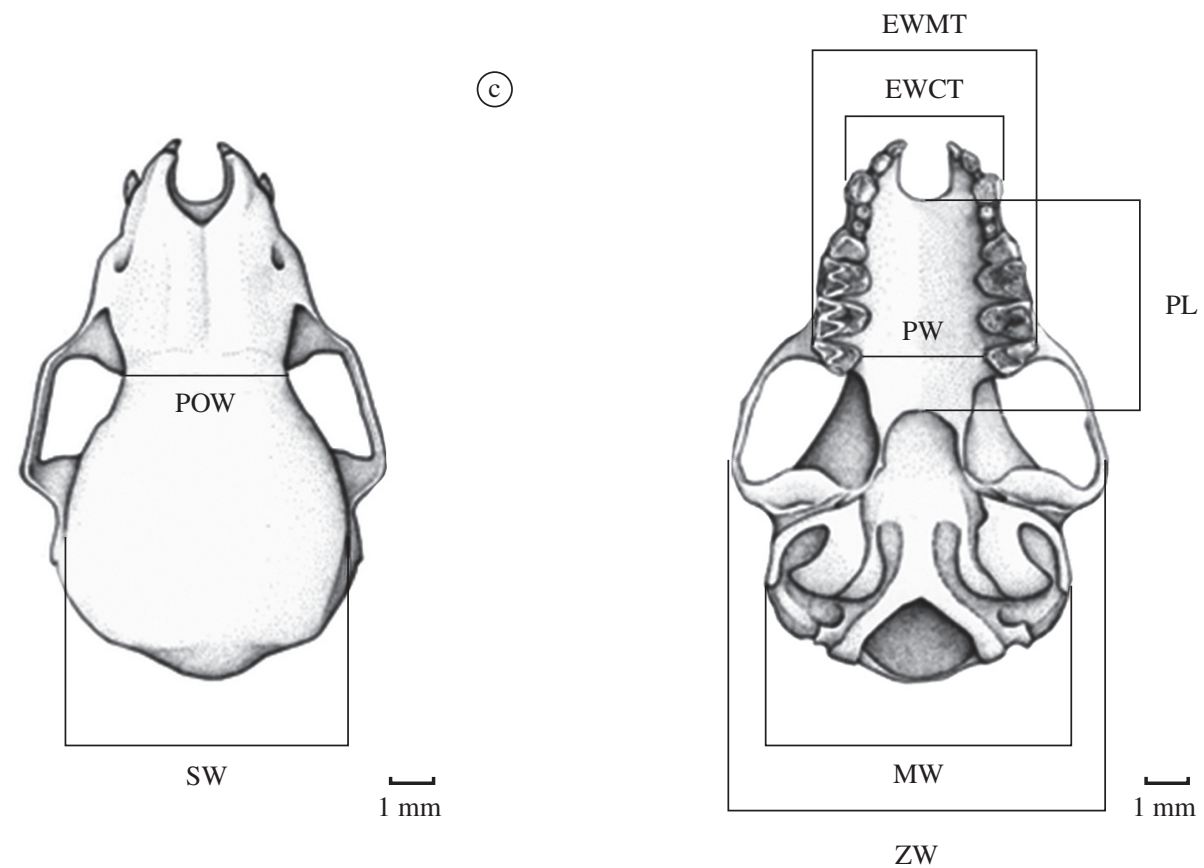

Figure 2. Forearm and skull linear measurements analyzed in the study. a) forearm. b) lateral view of the skull. c) dorsal view of the skull. and d) ventral view of the skull. FL: forearm length, TSL: total skull length, PL: palatal length, EWCT: external width of the canine teeth, EWMT: external width of the third molar teeth, PW: palatal width, POW: post orbital width, ZW: zygomatic width, SW: skull width, MW: mastoid width, SH: skull height. 
All statistical analyses of the traditional morphometrics were performed using SPSS 11.5 (SPSS for Windows, Lead Technologies Inc, Chicago).

\section{Results}

The Student's $t$-test results indicated sexual size dimorphism on the forearm length and on five in 10 studied skull measurements (see Table 2): total skull length (TSL), palatal length (PL), external width of the canine teeth (EWCT), zygomatic width (ZW) and skull height (SH). In all linear measurements females were larger than males $(\mathrm{P}<0.05)$.

In PCA, the first principal component (PC1) explained $56.07 \%$ and the second (PC2) explained $10.5 \%$ of the total observed variability. The measurements which contributed the most to PC1 were: total skull length (TSL), skull width (SW) and mastoid width (MW). Nevertheless, multivariate analysis of the Principal Components (from the ten skull measurements) was not sensitive enough to detect sexual dimorphism, and no a priori group formed by gender was detected. In addition, there is a trend demonstrated by the regression of the PCA residuals against the logarithm from the forearm length, suggesting that size (PC1) covariates with the forearm length (Figure 3 ). Females also have larger forearm length, as previously mentioned.

\section{Discussion}

The results of this paper showed sexual size dimorphism in the forearm length and in some measurements in the skull of M. nigricans in South Brazil. Females were larger than males.

Sexual dimorphism is a widespread phenomenon and there is a variety of reasons for its occurrence. Sexual selection (Darwin, 1871) acting through female choice or male-male competition is the explanation most often cited; however, there are other important reasons (Slatkin, 1984; Shine, 1989). Ecological factors express direct interaction of members of each sex with their environment, whereas sexual selection results from interaction between the sexes. Intrinsic differences in the reproductive roles or different energetic needs to ensure successful reproduction could be sufficient to result in dimorphism (Slatkin, 1984). In many species, the selective process (costs of reproduction) producing sexual dimorphism result in dimorphism for overall body size (Fairbairn, 1997) and, for this explanation, the bigger

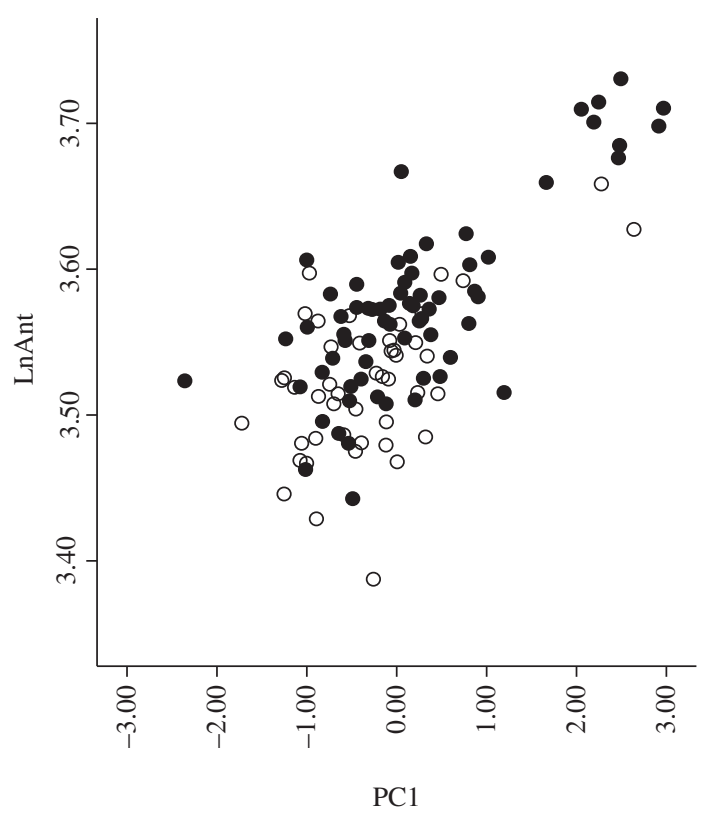

Figure 3. PC1 calculated using residuals of each measure and regressed by forearm length. Black circles: females; white circles: males.

Table 2. Mean, standard deviation (SD) and Student $t$ test result for sexual dimorphism of Myotis nigricans linear measurements $(\mathrm{mm})$ in South Brazil $(\mathrm{n}=$ sample number; $\mathrm{t}=\mathrm{t}$ value; d.f. $=$ degrees of freedom; $\mathrm{P}=$ significance $)$.

\begin{tabular}{|c|c|c|c|c|c|c|c|}
\hline Measurements & $\mathrm{n}$ & $\begin{array}{c}(q) \\
\text { Mean }(\mathrm{SD})\end{array}$ & $\mathrm{n}$ & $\begin{array}{c}\left(\widehat{O}^{\wedge}\right) \\
\operatorname{Mean}(\mathrm{SD})\end{array}$ & $\mathbf{t}$ & d.f. & $\mathbf{P}$ \\
\hline Ant & 57 & 35.15 (1.44) & 50 & $33.80(1.43)$ & 4.83 & 105 & $0.0001 * * *$ \\
\hline $\mathrm{CT}$ & 67 & $13.63(0.82)$ & 46 & $13.22(0.57)$ & 2.90 & 111 & $0.004 * *$ \\
\hline $\mathrm{CPT}$ & 67 & $5.59(0.46)$ & 46 & $5.40(0.48)$ & 2.07 & 111 & $0.041^{*}$ \\
\hline $\mathrm{LC}$ & 67 & $3.48(0.21)$ & 46 & $3.38(0.18)$ & 2.49 & 111 & $0.014^{*}$ \\
\hline LM & 67 & $5.40(0.42)$ & 46 & $5.30(0.30)$ & 1.37 & 111 & $0.172 \mathrm{~ns}$ \\
\hline LPT & 67 & $3.02(0.23)$ & 46 & $2.95(0.18)$ & 1.76 & 111 & $0.081 \mathrm{~ns}$ \\
\hline LP & 67 & $3.62(0.17)$ & 46 & $3.60(0.16)$ & 0.65 & 111 & $0.514 \mathrm{~ns}$ \\
\hline $\mathrm{LZ}$ & 67 & $8.22(0.59)$ & 46 & $7.93(0.58)$ & 2.58 & 111 & $0.011 *$ \\
\hline LCX & 67 & $6.64(0.35)$ & 46 & $6.56(0.32)$ & 1.26 & 111 & $0.211 \mathrm{~ns}$ \\
\hline LMT & 67 & $7.08(0.30)$ & 46 & $6.98(0.25)$ & 1.84 & 111 & $0.068 \mathrm{~ns}$ \\
\hline $\mathrm{ACX}$ & 67 & $4.96(0.22)$ & 46 & $4.82(0.25)$ & 2.95 & 111 & $0.004 * *$ \\
\hline
\end{tabular}


body size could be favored for the males but also for the females.

When the females are larger it is called reversed sexual dimorphism and it occurs in more lineages of mammals than is commonly perceived (Ralls, 1976). The bigmother hypothesis (Ralls, 1976) states that there could be some reasons for this phenomenon, but it is rarely the result of sexual selection. The most common selective pressures favoring large size in female mammals are probably those associated with the fact that a big mother gives their offspring better conditions, and those resulting from more intense competition among females than among males for some resource (Ralls, 1976).

Over the years, studies of bats have discussed sexual dimorphism in species where females are bigger than males (Ralls, 1976; Myers, 1978; Nicoll and Suttie, 1982; Gomes and Uieda, 2004; Rossiter et al., 2006). Among chiropterans, parental investment is large, because of the long time of gestation and lactation. Female chiropterans suckle their offspring until they are nearly adult size (Hayssen and Kunz, 1996). In this case, the additional mass that females carry during gestation and lactation is a clear consequence. This additional mass will be too high for effective flight and this presumably imposes a limit on the size of the offspring that females can transport, unless they can compensate (Hayssen and Kunz, 1996). Myers (1978) stated that bat females of Vespertilionidae are usually larger than males so as to perform parental care appropriately. Females, when pregnant, fly carrying their fetuses and, after that, they rear the infants in nursery colonies inside sheltered roots. Bat offspring are vulnerable during the pre-flight period and also during weaning, when they still depend on their mothers (Swift, 2001). As a consequence, nursery colonies are indeed energetically demanding for females (Kurta et al., 1989) and a bigger body size may be favorable in order to provide a successful reproductive process (Myers, 1978). Besides, an embryo of Myotis could represent as much as $25 \%$ of the maternal weight (Baydemir and Albayrak, 2006). Indeed, mothers must compensate for it.

Saunders and Barclay (1992) obtained for $M$. lucifugus and M. volans larger forearm length in females. For bats, length of forearm is a common estimate of body size. A usual assumption is that larger animals will have larger offspring and that larger offspring will require longer lengths of gestation and lactation. In Australia, Schulz (1999) concluded that females of Kerivoula papuensis (Vespertilionidae) had forearm length and body mass larger than males. Bogdanowicz and Owen (1996) found sexual size dimorphism in the skull of Otonycteris hemprichi (Vespertilionidae) using geometric morphometrics. Females presented larger centroid size than males. The results obtained in the current study confirm the data in the literature about sexual size dimorphism in vespertilionids.

In opposition to all these findings, the authors that have studied sexual dimorphism in M. nigricans (Myers and Wetzel, 1983; López-Gonzales et al., 2001) did not find significant differences between male and female measurements. The main reason for this divergence could be the fact that the authors did not sample specimens from Brazil; the specimens were, rather, from Argentina, Bolivia and Paraguay. It is true that these countries are quite close to each other, but it could be enough to characterize morphological variation in the species in South America. Additionally, López-Gonzales et al. (2001) recognized that sexual size dimorphism in witch females are larger than males is a well known and established phenomenon for the species of the Vespertilionidae family.

In fact, the locomotion mode likely to impose the greatest additional 'cost' for a pregnant female is flight. In this sense, natural selection has favored a suite of morphological changes that reduce the magnitude of this cost. Nevertheless, it may not be the only perception of the results found in this study. Instead of thinking in bigger size for the females, it could be thought as a decrease in size for the males. A brief explanation could be the small body size of males as an adaptation to increase maneuverability. Selection on agility to fly is expected to produce female-biased dimorphism if it is advantageous for males to use agility in flying (Shine et al., 1998; Székely et al., 2004). Clearly, this hypothesis is similar to the other described above, in that it relies upon sexspecific adaptation in species that fly.

In the absence of male-biased dimorphism and in the presence of high involvement of the female vespertilionids with their offspring, the sexual size dimorphism reported in this paper indicates a strong influence of ecological factors (natural selection) for dimorphism. Females of M. nigricans in South Brazil are bigger than the males, and this could be more clearly attributed to natural selection on large female size for increased fecundity. Moreover, in accordance with recent conclusions about sexual size dimorphism with a lack of malebiased dimorphism (Ortega et al., 2003; Rossiter et al., 2006), this should not be considered as evidence for reduced sexual competition (sexual selection), but rather, indicates that sexual selection is less visible.

Acknowledgements - We thank the collection managers for the admirable contribution in providing scientific material: Dra. Ana Maria Rui (Universidade Federal de Pelotas); Professor Hamilton Grillo and biologist Elisangela Mander (Centro Universitário UNIVATES); Dr. Sergio Althoff (Fundação Universitária da Região de Blumenau) and Dra. Márcia Jardim (Fundação Zoobotânica do Rio Grande do Sul). Thanks to Erika Hingst-Zaher and Fábio de Andrade Machado for their help in the multivariate analysis and Tiago Giora for his help in the text. We also thank the anonymous referee for the productive comments and suggestions. Finally, we thank $\mathrm{CNPq}$ (Conselho Nacional do Desenvolvimento Científico e Tecnológico), which provided the MSc. grant to Renata Bornholdt. This study is part of the dissertation presented by R. B., submitted in partial fulfillment for an MSc. degree in Animal Biology at the Universidade Federal do Rio Grande do Sul, Brazil. 


\section{References}

ANTHONY, ELP., 1988. Age determination in bats. In T. H. Kunz (Ed.). Ecological and behavioral methods for the study of bats, Smithson. Washington, D.C.: Inst. Press. 533 p.

BARQUEZ, RM., MARES, MA. and BRAUN, JK., 1999. The bats of Argentina. Lubbock: Museum of Texas Tech University. $275 \mathrm{p}$.

BAUD, FJ. and MENU, H., 1993. Paraguayan bats of the genus Myotis, with a redefinition of M. simus (Thomas, 1901). Rev. Suisse Zool., vol. 100, no. 3, p. 595-607.

BAYDEMIR, NA. and ALBAYRAK, I., 2006. A study on the breeding biology of some bat species in Turkey (Mammalia: Chiroptera). Turk. J. Zool., vol. 30, p. 103-110.

BIANCONI, GV. and PEDRO, WA., 2007. Família Vespertilionidae. In REIS, NR., PERACCHI, AL., PEDRO, WA. and LIMA, IP. (Eds.). Morcegos do Brasil. Londrina: Universidade Estadual de Londrina. 253 p.

BOGAN, MA., 1978. A new species of Myotis from the Islas Tres Marias, Nayarit, Mexico, with comments on variation in Myotis nigricans. J. Mammal., vol. 59, no. 3, p. 519-530.

BOGDANOWICZ, W. and OWEN, RD., 1996. Landmarkbased size and shape analysis in systematics of the Plecotine bats. In MARCUS, LF., CORTI, M., LOY, A., NAYLOR, GJP. and SLICE, D. (Eds.). Advances in Morphometrics. New York: Plenum Press. 587 p.

BURNETT, CD. and KUNZ, TH., 1982. Growth rates and age estimation in Eptesicus fuscus and comparison with Myotis lucifugus. J. Mammal., vol. 63, no. 1, p. 33-41.

CAMPBELL, NA. and KITCHENER, DJ., 1980. Morphological divergence in the genus Eptesicus (Microchiroptera: Vespertilionidae) in Western Australia: a multivariate approach. Aust. J. Zool., vol. 28, p. 457-474.

DARWIN, C., 1871. The descent of man and selection in relation to sex. London: Murray Press. $424 \mathrm{p}$.

FAIRBAIRN, DJ., 1997. Allometry for sexual size dimorphism: pattern and process in the coevolution of body size in males and females. Ann. Rev. Ecol. Syst., vol. 28, p. 659-687.

GANNON, WL., SHERWIN, RE., DE CARVALHO, TN. and O'FARREL, MJ., 2001. Pinnae and echolocation call differences between Myotis californicus and M. ciliolabrum (Chiroptera: Vespertilionidae). Acta Chiropt., vol. 3, no. 1, p. 77-91.

GOMES, MN. and UIEDA, W., 2004. Abrigos diurnos, composição de colônias, dimorfismo sexual e reprodução do morcego hematófago Desmodus rotundus (E. Geoffroy) (Chiroptera, Phyllostomidae) no Estado de São Paulo, Brasil. Revta. Bras. Zool., vol. 21, no. 3, p. 629-638.

GONZÁLEZ, JC., 2000. Morcegos da área urbana de Porto Alegre, Rio Grande do Sul, Brasil. Divulg. Mus. Ciênc. Tecnol. - PUCRS, vol. 1, no. 5, p. 53-82.

HAYSSEN, V. and KUNZ, TH., 1996. Allometry of litter mass in bats: maternal size, wing morphology, and phylogeny. $J$. Mammal., vol. 77, no. 2, p. 476-490.

HOOFER, SR. and BUSSCHE, RAVD., 2003. Molecular phylogenetics of the chiropteran family Vespertilionidae. Acta Chiropt., vol. 5, supl., p. 1-63.
KUNZ, TH. and ANTHONY, ELP., 1982. Age estimation and post-natal growth in the bat Myotis lucifugus. J. Mammal., vol. 63 , no. 1 , p. 23-32.

KURTA, A., BELL, GP., NAGY, K. A. \& KUNZ, TH., 1989. Energetics of pregnancy and lactation in free-ranging little brown bats (Myotis lucifugus). Physiol. Zool., vol. 62, p. 804-818.

LAVAL, RK., 1973. A revision of the Neotropical bats of the genus Myotis. Bul. Natu. Hist., vol. 15, p. 1-54.

LÓPEZ-GONZÁLEZ, C., PRESLEY, SJ., OWEN, RD. and WILLIG, MR., 2001. Taxonomic status of Myotis (Chiroptera: Vespertilionidae) in Paraguay. J. Mammal., vol. 82, no. 1, p. $138-160$.

MARCUS, LF., 1990. Tradicional morphometrics. In ROHLF, FJ. and BOOKSTEIN, FL. (Eds.). Proceedings of the Michigan Morphometrics Workshop: Special Publication. Michigan: The University of Michigan Museum of Zoology.

MYERS, P., 1978. Sexual dimorphism in size of vespertilionid bats. Am. Nat., vol. 112, p. 701-711.

MYERS, P. and WETZEL, RM., 1983. Systematic and zoogeography of the bats of the Chaco Boreal. Miscel. Public., p. 1-59.

NEFF, N. and MARCUS, LF., 1980. A survey of multivariate methods for systematic. New York: American Museum of Natural History.

NICOLL, ME. and SUTTIE, JM., 1982. The Sheath-tailed, Coleura seychellensis (Chiroptera: Emballonuridae) in the Seychelles Islands. J. Zool., vol. 197, p. 421-426.

ORTEGA, J., MALDONADO, JE., WILKINSON, GS., ARITA, HT. and FLEISCHER, RC., 2003. Male dominance, paternity, and relatedness in the Jamaican fruit-eating bat (Artibeus jamaicensis). Mol. Ecol., vol. 12, p. 2409-2415.

RALLS, K., 1976. Mammals in which females are larger than males. Quart. Rev. Biol., vol. 51, p. 245-276.

REDUKER, DW., 1983. Functional analysis of the masticatory apparatus in two species of Myotis. J. Mammal., vol. 64, no. 2, p. $277-286$

ROSSITER, SJ., RANSOME, RD., FAULKES, CG., DAWSON, DA. and JONES, G., 2006. Long-term paternity skew and the opportunity for selection in a mammal with reversed sexual size dimorphism. Mol. Ecol., vol. 15, p. 3035-3043.

RUEDI, M., ARLETTAZ, R. and MADDALENA, T., 1990. Distinction morphologique et biochimique de deux espèces jumelles de chauvez-souris: Myotis myotis (Bork.) et Myotis blythi (Tomes) (Mammalia: Vespertilionidae). Mammalia, vol. 54 , no. 3, p. 415-429.

RUEDI, M. and MAYER, F., 2001. Molecular systematics of bats of the genus Myotis (Vespertilionidae) suggests deterministic ecomorphological convergences. Mol. Phylogenet. Evol., vol. 21 , no. 3 , p. 436-448.

SAUNDERS, MB. and BARCLAY, RMR., 1992. Ecomorphology of insectivorous bats: a test of predictions using two morphologically similar species. Ecology, vol. 73, no. 4, p. 1335-1345.

SCHULZ, M., 1999. Relative abundance and other aspects of the natural history of the rare golden-tipped bat, Kerivoula papuensis (Chiroptera: Vespertilionidae). Acta Chiropt., vol. 1, no. 2, p. 165-178. 
SHINE, R., 1989. Ecological causes for the evolution of sexual dimorphism: a review of the evidence. Quart. Rev. Biol., vol. 64, no. 4, p. 419-461.

SHINE, R., KEOGH, S., DOUGHTY, P. and GIRAGOSSYAN, H., 1998. Costs of reproduction and the evolution of sexual dimorphism in a 'flying lizard' Draco melanopogon (Agamidae). J. Zool., vol. 246, p. 203-213.

SIEMERS, BM., KALKO, EKV. and SCHNITZLER, HU., 2001. Echolocation behavior and signal plasticity in the Neotropical bat Myotis nigricans (Schinz, 1821) (Vespertilionidae): a convergent case with European species of Pipistrellus? Behav. Ecol. Sociobiol., vol. 50, p. 317-328.

SIMMONS, NB., 2005. Order Chiroptera. In WILSON, DE. and REEDER, DM. (Eds.). Mammal species of the world: a taxonomic and geographic reference. Baltimore: Johns Hopkins University Press. p. 312- 529.
SLATKIN, M., 1984. Ecological causes of sexual dimorphism. Evolution, vol. 38, no. 3, p. 622-630.

STADELMANN, B., HERRERA, LG., ARROYO-CABRALES, J., FLORES-MARTÍNEZ, JJ., MAY, BP. and RUEDI, M., 2004. Molecular systematics of the fishing bat Myotis vivesi. J. Mammal, vol. 85, no. 1, p. 133-139.

SWIFT, S., 2001. Growth rate and development in infant Natterer's bats (Myotis nattereri) reared in a flight room. Acta Chiropt., vol. 3, no. 2, p. 217-223.

SZÉKELY, T., FRECKLETON, RP. and REYNOLDS, JD., 2004. Sexual selection explains Rensch's rule of size dimorphism in shorebirds. PNAS, vol. 101, no. 33, p. 12224-12227.

VIZOTTO, LD. and TADDEI, VA., 1973, Chave para determinação de quirópteros brasileiros. Bol. Ciências, vol. 1, p. 1-72. 


\section{Appendix}

Specimens examined: The 117 adult specimens used in this study were obtained from the following collections: Departamento de Zoologia da Universidade Federal do Rio Grande do Sul (ZMAM); Fundação Universitária da Região de Blumenau (FUR-SLA); Museu de Ciências Naturais da Fundação Zoobotânica do Rio Grande do Sul (MCN); Museu de Ciências Naturais do Centro Universitário UNIVATES (ZMUMCN).

South Brazil Region - Paraná state (PR). Cities:

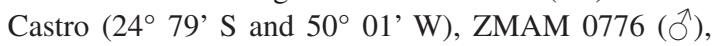
ZMAM $0780\left(\delta^{\AA}\right)$; Londrina (23⒊' $\mathrm{S}$ and $\left.51^{\circ} 16^{\prime} \mathrm{W}\right)$, ZMAM 0775 (ㅇ), ZMAM 0777-0778 (ठ). Santa Catarina state (SC). Cities: Água Doce $\left(26^{\circ} 99^{\prime} \mathrm{S}\right.$ and 51 ${ }^{\circ} 16^{\prime} \mathrm{W}$ ), FURB-SLA 1726 (ㅇ), FURB-SLA 1730 (ㅇ) ); Blumenau (26 $96^{\circ} \mathrm{S}$ and $\left.49^{\circ} 05^{\prime} \mathrm{W}\right)$, FURB-SLA 1634

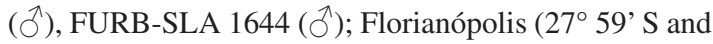
$48^{\circ}$ 54'W), FURB-SLA 0057 (), FURB-SLA 0111 (q), FURB-SLA 0238-0240 (ðَ), FURB-SLA 0241

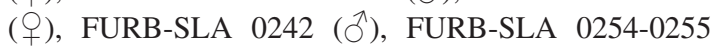
(q), FURB-SLA 0256 ( $\left.{ }^{\lambda}\right)$, FURB-SLA 0257-0258 (q), FURB-SLA 0282 (ð), FURB-SLA 0283-0284 (q), FURB-SLA 0286 (ㅇ), FURB-SLA 0288 ( ఏ), FURBSLA 0289-0290 (), FURB-SLA 0305 (ð), FURBSLA 0306-308 (), FURB-SLA 0313 ( ðُ), FURB-SLA 0314 (ㅇ), FURB-SLA 0318 (すへ), FURB-SLA 0320 (す), FURB-SLA 321-0323 (), FURB-SLA 0352-0353 (ðَ), FURB-SLA 0360-0361 (ð), FURB-SLA 0552-0553 (ð), FURB-SLA 0560 (q), FURB-SLA 0707 (), FURB-SLA 1022 ( $\left.{ }^{\lambda}\right)$; Gaspar (26 $6^{\circ} 55^{\prime} \mathrm{S}$ and $\left.48^{\circ} 57^{\prime} \mathrm{W}\right)$, FURB-SLA 0075 ( 9 ); Indaial (26 $86^{\circ} \mathrm{S}$ and $49^{\circ} 23^{\prime}$ W), FURB-SLA 1740 (ठ̋), FURB-SLA 1781 (q), FURB-SLA 1783 (ㅇ), FURB-SLA 1802 (ð̋), FURBSLA $1811(ð)$, FURB-SLA 1823 ()); Jaraguá do Sul
(26 $29^{\prime}$ 'S and $\left.49^{\circ} 04^{\prime} \mathrm{W}\right)$, FURB-SLA 1875 (ð̋); Joinville ( $26^{\circ} 30^{\prime} \mathrm{S}$ and $48^{\circ} 84^{\prime} \mathrm{W}$ ), FURB-SLA 0063 (q); Nova Veneza (28 63' S and 49 49' W), FURB-SLA 0897 ( $\left.{ }^{\top}\right)$ ), FURB-SLA 0902 (), FURB-SLA 0908 (ㅇ) ; Pomerode (26 $74^{\prime} \mathrm{S}$ and $49^{\circ} 17^{\prime} \mathrm{W}$ ), FURB-SLA 1220-1222 (ㅇ); Santa Rosa do Sul (29 08' S and $49^{\circ} 42^{\prime}$ W), FURBSLA 0914 () , FURB-SLA 0918 (ठ̋), FURB-SLA 0920 (q). Rio Grande do Sul state (RS). Cities: Anta Gorda ( $28^{\circ} 58^{\prime} \mathrm{S}$ and $52^{\circ} 00^{\prime} \mathrm{W}$ ), MCN 0556-0557 ( ${ }^{\circ}$ ); Arroio do Meio (29 24' S and 51 $\left.{ }^{\circ} 56^{\prime} \mathrm{W}\right)$, ZMUMCN 0391 (ठ̋); Caxias do Sul (29 $10^{\prime} \mathrm{S}$ and $\left.51^{\circ} 10^{\prime} \mathrm{W}\right)$, ZMAM 0078 (ㅇ), ZMAM 0079 (ठํ), ZMAM 0080 (q); Dom Pedro de Alcântara (29 $22^{\prime} \mathrm{S}$ and $49^{\circ}$ 50' W), ZMAM 0195 (ㅇ), ZMAM 0196 (ð̋), ZMAM 0197 (우), ZMAM

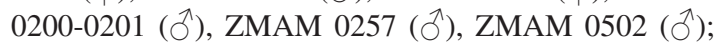
Forquetinha $\left(29^{\circ} 22^{\prime} \mathrm{S}\right.$ and $\left.52^{\circ} 05^{\prime} \mathrm{W}\right), \mathrm{ZMUMCN} 0648$ (q); General Câmara (29 $54^{\prime} \mathrm{S}$ and $\left.51^{\circ} 45^{\prime} \mathrm{W}\right)$, ZMAM 0165 (ㅇ); Guaíba (30 06' S and 51 $\left.{ }^{\circ} 19^{\prime} \mathrm{W}\right)$, MCN 2351 (ठ); Lajeado (29 $28^{\prime} \mathrm{S}$ and $\left.51^{\circ} 57^{\prime} \mathrm{W}\right)$, ZMUMCN 0225-0226 (đ̊), ZMUMCN 0652 (ㅇ); Maquiné $\left(29^{\circ} 40^{\prime} \mathrm{S}\right.$ and $\left.50^{\circ} 12^{\prime} \mathrm{W}\right)$, ZMAM 0006 (ㅇ), ZMAM 0057 (), ZMAM 0751-0753 (q), ZMAM 0755-756

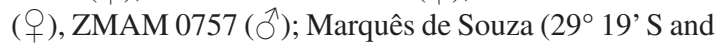

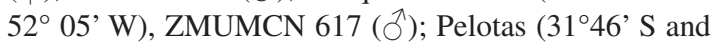
$\left.52^{\circ} 20^{\prime} \mathrm{W}\right)$, ZMAM 0732 (ठ̋), ZMAM 0735 (ㅇ),

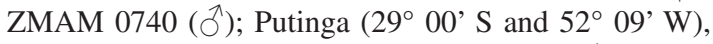
ZMUMCN 0265 (ㅇ), ZMUMCN 0509 ( $\left.0^{\lambda}\right)$; Santa Maria (29 $41^{\prime} \mathrm{S}$ and $\left.53^{\circ} 49^{\prime} \mathrm{W}\right), \mathrm{MCN}$ 0289-0290 (q), MCN 0292 (q) , MCN 0293 (ổ), MCN 0294-0299 (), MCN 0301 (đđ); São José do Herval (2902' S and $52^{\circ}$ 17' W), ZMUMCN 0383 (ㅇ); São Lourenço do Sul

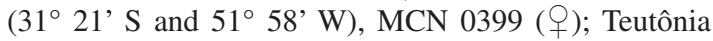

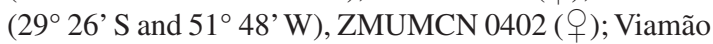
(30 $04^{\prime} \mathrm{S}$ and $\left.51^{\circ} 01^{\prime} \mathrm{W}\right)$, ZMAM 0782 (ㅇ), ZMAM 0783 (ふ), ZMAM 0785-0786 (ふ). 